\title{
OPTIMAL SELECTION OF HYDRAULIC TURBINES FOR SMALL HYDRO ELECTRIC POWER GENERATION - A CASE STUDY OF OPEKI RIVER, SOUTH WESTERN NIGERIA
}

\author{
I. A. Adejumobi ${ }^{1,}{ }^{*}$ and D. I. Shobayo ${ }^{2}$ \\ 1,2 Dept. of Electrical \& Electronics Engr'NG, Federal Univ. of Agriculture, AbeokUta, OGUn State. NiGERIA \\ E-mail addresses: ${ }^{1}$ engradejumobi@yahoo.com, ${ }^{2}$ deleshobayo@gmail.com
}

\begin{abstract}
The overall net annual energy production from Small Hydro Power (SHP) scheme using stream flow or run-of-water is usually depend on the water height (head), stream flow (discharge) and turbine efficiency. However, experience has shown that the annual capacity of the plant which is a measure of what the machine can deliver throughout the year without interruption is usually in conflict with theoretical power rated output when analysed with different turbines and subjected to the same values of the above mentioned variables. This work provided a platform for optimum selection of SHP turbine for optimum power output that can be sustained throughout the year. Conventional power Equations, seven years of mean daily flow and a medium range of gross head of Opeki River, Ogun State, Nigeria were used to develop Flow Duration Curve (FDC) and annual energy production of a proposed SHP power plant. $A$ net head of $37 \mathrm{~m}$ and reserved flow of $2.97 \mathrm{~m}^{3} / \mathrm{s}$ was used. Seven hydraulic turbines were examined using their permissible efficiencies. Results from the analysis showed that turbines that gave maximum and minimum power outputs respectively did not imply maximum and minimum annual capacities. The study indicates the usefulness of this work as a guide for SHP scheme.
\end{abstract}

Keywords: optimal selection, SHP turbine, flow duration curve, energy efficiency, annual capacity factor

\section{INTRODUCTION}

Small hydro power (SHP) has the potential to become an important contributor to global energy; especially, in developing countries like Nigeria [1, 2]. With rural electricity access levels at approximately $28 \%$, Nigeria faces an acute shortage of rural electricity supply [3]. Most potential small hydro sites in Nigeria are located within the proximity of off - grid, rural communities [4] where potential beneficiaries have limited access to finance [3]. As a consequence, technological challenges alongside the cost associated with assessing potential SHP sites have served as substantial barriers to the widespread development of SHP in Nigeria $[5,6,7]$.

SHP schemes usually have facilities with rated output of $10 \mathrm{MW}$ or less $[8,9]$. Since the primary objective of SHP generation is to maximize plant energy production at minimal cost; a SHP does not need the large reservoirs generally associated with large scale hydroelectric power generation. Most SHPs are run - of - river projects without significant water storage facilities $[9,10]$. As a consequence, turbine efficiency, and; the plant's power output fluctuates with the annual variability of the river flow to be exploited [8]. Since the turbine is the primary energy conversion machinery in a SHP; an evaluation of the hydrodynamic response of alternative hydraulic turbines to the annual variability of stream flow is a prerequisite to appropriate turbine selection. Optimum turbine selection leads to maximization of annual energy production. Failure to do so, often leads to a significant deficit in annual energy production and low annual plant capacity $[8,9]$. Turbine selection depends mainly upon the site characteristics; principally, available head and the flow regime of the river to be exploited $[10,11]$. The aforementioned characteristics also determine the energy available at the study area. The extensive nature of these evaluations necessitated the development of an algorithm in Visual Basic programming language to implement the design. 


\section{EQUATIONS AND FORMULAE}

Various mathematics and expression describing procedural steps in choosing appropriate SHP components are presented below.

\subsection{Annual Flow Duration Curve (FDC)}

A reliable assessment of available energy at a potential small hydro site begins with an understanding of the annual flow characteristics of the river. Rivers annual flow characteristics are depicted by the FDC. It summarizes the hydrological characteristics of river flow [12]. FDC is a curve with probability of exceedance (\%) on the $\mathrm{x}$ - axis and the flow rate $\left(\mathrm{m}^{3} / \mathrm{s}\right)$ on the $\mathrm{y}$ axis, which provides information on the probability of a specific flow being equalled or exceeded $[12,13]$. Development of FDC from mean daily flow records can be achieved by using statistical applications.

In order to avoid sections of the watercourse being depleted, with adverse environmental impacts downstream, a minimum non-usable flow is usually prescribed by environmental regulations to bypass the SHP $[8,9]$. This minimum flow, also termed the reserved flow $\left(\mathrm{Q}_{\mathrm{r}}\right)$, must remain unused when abstracting water from a river to drive the turbine. Given $Q_{i}$ represent flow values constituting the FDC for the river to be exploited. The actual flows available to the turbine for power generation, termed $Q_{j}$, is estimated using Equation (1) [8, 9];

$$
Q_{j}=Q_{i}-Q_{r}
$$

Where, $i, j=\{0,1,2,3, \ldots, n\}, i, j$ are subscripts indicating the exceedance probability of each flow on the FDC, $n$ is the number of equally spaced intervals on the FDC, $Q_{i}$ is the flows constituting the primary $\mathrm{FDC}\left(\mathrm{m}^{3} / \mathrm{s}\right)$,

$\mathrm{Q}_{\mathrm{j}}$ is the flows constituting the secondary FDC $\left(\mathrm{m}^{3} / \mathrm{s}\right)$, $\mathrm{Q}_{\mathrm{r}}$ is the reserved flow $\left(\mathrm{m}^{3} / \mathrm{s}\right)$.

\subsection{Head (H)}

The gross head is the vertical distance between upper to lower surface water levels [8, 11]. Estimation of gross head can be made from large topographical maps or by field measurements using leveling or total station. Both methods were used to estimate gross head in this study. After measuring the gross head, allowances must be made for the losses associated with the water conveyance structures and tail water effect. Therefore, the actual head available for power generation, termed the net head $\left(\mathrm{H}_{\mathrm{n}}\right)$, was estimated using Equation (2) [8,10]:

$$
\mathrm{H}_{\mathrm{n}}=\mathrm{H}_{\mathrm{g}}-\left[\zeta_{\mathrm{h}}\left(\mathrm{H}_{\mathrm{g}}\right)+\mathrm{h}_{\mathrm{w}}\right]
$$

Where, $H_{n}$ is the net head (m), $H_{g}$ is the gross head $(\mathrm{m}), \zeta_{\mathrm{h}}$ is the maximum hydraulic losses (typically $3-$ $8 \%), \mathrm{h}_{\mathrm{w}}$ is the maximum tail water level $(\mathrm{m})$.

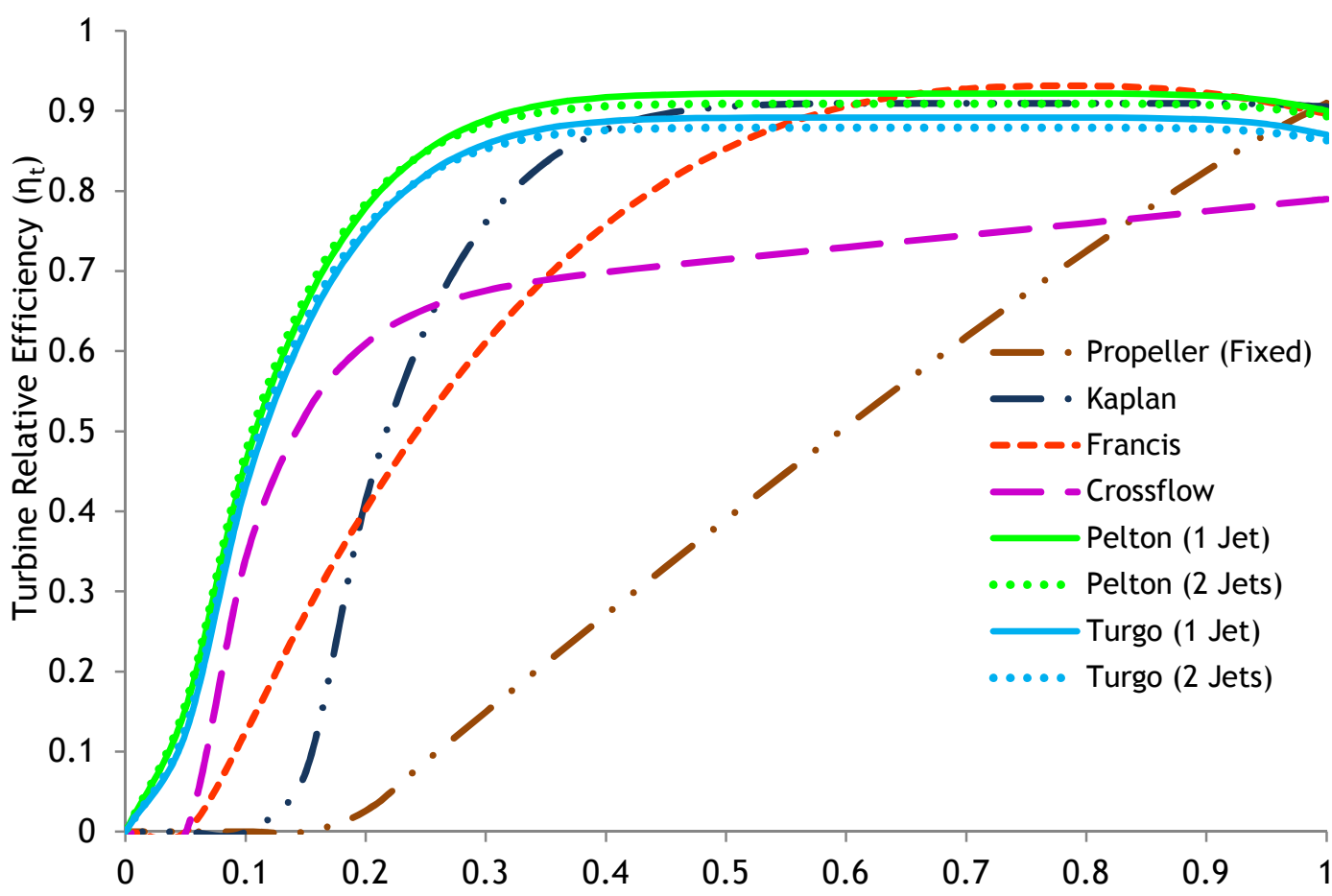

Available flow as a fraction of Rated Flow $\left(Q_{j} / Q_{k}\right)$

Figure 1. Turbine Efficiency Curves 


\subsection{Turbine relative efficiency}

A hydraulic turbine's relative efficiency describes a turbine's efficiency at design flow and reduced flows as depicted by a turbine efficiency curve (TEC). The relative efficiency of a specific turbine was determined by the energy conversion technology employed by turbine $[8,9]$. Studies carried out on Kaplan, Propeller, Francis, Crossflow, Pelton and Turgo turbines have established formulae to determine their relative efficiencies under varying conditions of head and flow. The details of the formulae are described in details in [10], the procedures were adopted to develop the turbine efficiency curves used in this study as presented in Figure 1.

\subsection{Power output of a SHP}

Considering the overall efficiency of components in the SHP; the power output of the plant was estimated using Equation (3) [11]:

$$
\mathrm{P}=\rho \mathrm{gQH}_{\mathrm{n}} \eta_{\mathrm{o}}
$$

where, $\rho$ is the water specific density $\left(1000 \mathrm{~kg} / \mathrm{m}^{3}\right), \mathrm{g}$ is the acceleration due to gravity $\left(9.8 \mathrm{~m} / \mathrm{s}^{2}\right), \mathrm{Q}$ is the stream flow $\left(\mathrm{m}^{3} / \mathrm{s}\right), \mathrm{H}_{\mathrm{n}}$ is the net head $(\mathrm{m})$ and $\eta_{\mathrm{o}}$ is the overall efficiency of the system (\%).

\subsection{Power duration curve (PDC)}

The PDC depicts the power output of the SHP in response to the annual variability of streamflow. Modification of the Equation 3 to consider the distinct efficiencies and losses of various components at the SHP and taking $Q_{k}$ as the plant's rated flow, Equation 4 defines the power output of the SHP scheme due to the available flow $\left(\mathrm{Q}_{\mathrm{j}}\right)$, relative to the plant's rated flow $\left(\mathrm{Q}_{\mathrm{k}}\right)$ [10]. Hydraulic head losses $\left(\mathrm{H}_{\mathrm{h}}\right)$ were estimated using Equation 5.

$$
\begin{gathered}
P_{k(j)}=\rho g Q_{j}\left[H_{g}-\left(H_{h}+H_{w}\right)\right] \eta_{t ~ k(j)} \eta_{g}(1 \\
\left.-\zeta_{t}\right)\left(1-\zeta_{t}\right)
\end{gathered}
$$

In $(4) j, k=\{0,1,2,3, \ldots, n\}, n$ is the number of equally spaced intervals on the FDC, $Q_{j}$ is the min $\left(Q_{j}, Q_{k}\right)$, " $j$ " and " $\mathrm{k}$ " indicate the exceedance probability of a flow value on the FDC, $\eta_{t}$ is the turbine relative efficiency (obtained from Figure 1), $\eta_{\mathrm{g}}$ is the generator efficiency (typically $93-97 \%$ ), $\zeta_{t}$ is the transformer losses (typically $1-3 \%$ ), $\zeta_{\mathrm{p}}$ is the parasitic electricity losses (typically $1-4 \%), \rho$ is the density of water $(1,000$ $\left.\mathrm{kg} / \mathrm{m}^{3}\right)$, $\mathrm{g}$ is the acceleration of gravity $\left(9.81 \mathrm{~m} / \mathrm{s}^{2}\right), \mathrm{Q}_{\mathrm{j}}$ is the available flows $\left(\mathrm{m}^{3} / \mathrm{s}\right), \mathrm{Q}_{\mathrm{k}}$ is the plant's rated flow $\left(\mathrm{m}^{3} / \mathrm{s}\right), \mathrm{H}_{\mathrm{g}}$ is the gross head $(\mathrm{m})$ and $\mathrm{H}_{\mathrm{h}}$ is the hydraulic head losses (adjusted over the range of available flows)

$$
\mathrm{H}_{\mathrm{h}}=\mathrm{H}_{\mathrm{g}} \zeta_{\mathrm{h}}\left\{\mathrm{Q}_{\mathrm{j}}^{2} / \mathrm{Q}_{\mathrm{k}}^{2}\right\}
$$

where $\zeta_{\mathrm{h}}$ is the maximum hydraulic losses (typically 3 - 7\%). Equation 6 presents the tail water losses over the range of available flow.

$$
\mathrm{H}_{\mathrm{w}}=\mathrm{h}_{\mathrm{w}}\left\{\left(\mathrm{Q}_{\mathrm{j}}-\mathrm{Q}_{\mathrm{k}}\right)^{2} /\left(\mathrm{Q}_{\max }-\mathrm{Q}_{\mathrm{k}}\right)^{2}\right\}
$$

Where $H_{w}$ is the tail water head losses (adjusted over the range of available flows) and are defined for only $\left(Q_{j}>Q_{k}\right) ; h_{w}$ is the maximum tail water level (m) and $Q_{\max }$ is the maximum river flow obtained from the primary FDC $\left(\mathrm{m}^{3} / \mathrm{s}\right)$.

The plant's rated output $\left(\mathrm{P}_{\mathrm{k}}\right)$ was obtained from the Equation 4 when $Q_{k}=Q_{j}$ and the power outputs from the Equation was used to establish power duration curve (PDC) for the proposed plant using alternative turbines.

The plant's rated output $\left(\mathrm{P}_{\mathrm{k}}\right)$ when rated flow equals the minimum annual flow (i.e. $Q_{k}=Q_{\min }$ ) defines the minimum power potential $\left(\mathrm{P}_{\min }\right)$ of the plant [14].

The plant's rated output $\left(\mathrm{P}_{\mathrm{k}}\right)$ when rated flow equals the mean annual flow (i.e. $Q_{k}=Q_{\text {mean }}$ ) defines the average power potential $\left(\mathrm{P}_{\text {mean }}\right)$ of the plant [14].

\subsection{Annual energy production (E)}

An approximation of the area of the region under the power duration curve provides an estimate of the SHP's annual energy projection. The area was approximated by mathematical expression presented in (7).

$$
\int_{\mathrm{a}}^{\mathrm{b}} \mathrm{f}(\mathrm{x}) \mathrm{dx}=\frac{\mathrm{h}}{2} \sum_{\mathrm{z}=0}^{\mathrm{n}}\left\{\mathrm{f}\left(\mathrm{x}_{\mathrm{z}}\right)+\mathrm{f}\left(\mathrm{x}_{\mathrm{z}+1}\right)\right\}
$$

The trapezoidal rule was modified to accommodate the plant's availability as presented in (8) [15]:

$$
\mathrm{E}=\frac{\mathrm{h}}{2} \sum_{\mathrm{j}=0}^{\mathrm{n}}\left\{\mathrm{P}_{\mathrm{k}(\mathrm{j})}+\mathrm{P}_{\mathrm{k}(\mathrm{j}+1)}\right\} \mathrm{t}_{\mathrm{y}}
$$

In (8), $\mathrm{E}$ is the the annual energy produced by the SHP $(\mathrm{kWh}), \mathrm{P}_{\mathrm{k}(\mathrm{j})}$ is the power outputs from (4), A = plant's annual availability (typically $85-98 \%$ ), $\mathrm{t}_{\mathrm{y}}$ is the approximated number of hours in a year (8760 hrs), h is the percentage spacing of intervals on the PDC (1\%).

\subsection{Annual capacity factor(C)}

SHP annual capacity factor is the ratio of the plant's estimated energy production to the plant's potential energy production if it had operated at rated output for the whole year [8]. A higher capacity factor plant is more dependable. Annual capacity was estimated using Equation $9[8,10]$;

$$
\mathrm{C}=E /\left(\mathrm{P}_{\mathrm{k}} \mathrm{t}_{\mathrm{y}}\right)
$$

Where $\mathrm{C}$ is the plant capacity factor 


\subsection{Turbine application range chart}

Given specific site characteristics of head and flow, turbine application range charts have been developed to assist with the selection of appropriate turbine(s). These charts are shown in Figures 2 and 3. A combination of net head and rated flow fall within the operational envelope of an appropriate turbine. Envelopes of alternative turbines may overlap and slight variations exist among charts produced by different manufacturers.

\section{ANALYSIS AND DISCUSSION}

Seven years mean daily flow $\left(\mathrm{m}^{3} / \mathrm{s}\right)$ and head $(\mathrm{m})$ were collected from Opeki river, Ogun State, Nigeria. The study area is located at Abidogun Village, Iseyin Local Government Area, Oyo State, Nigeria. It is under the jurisdiction of Authority: Ogun-Osun River Basin Development Authority (OORDBA).

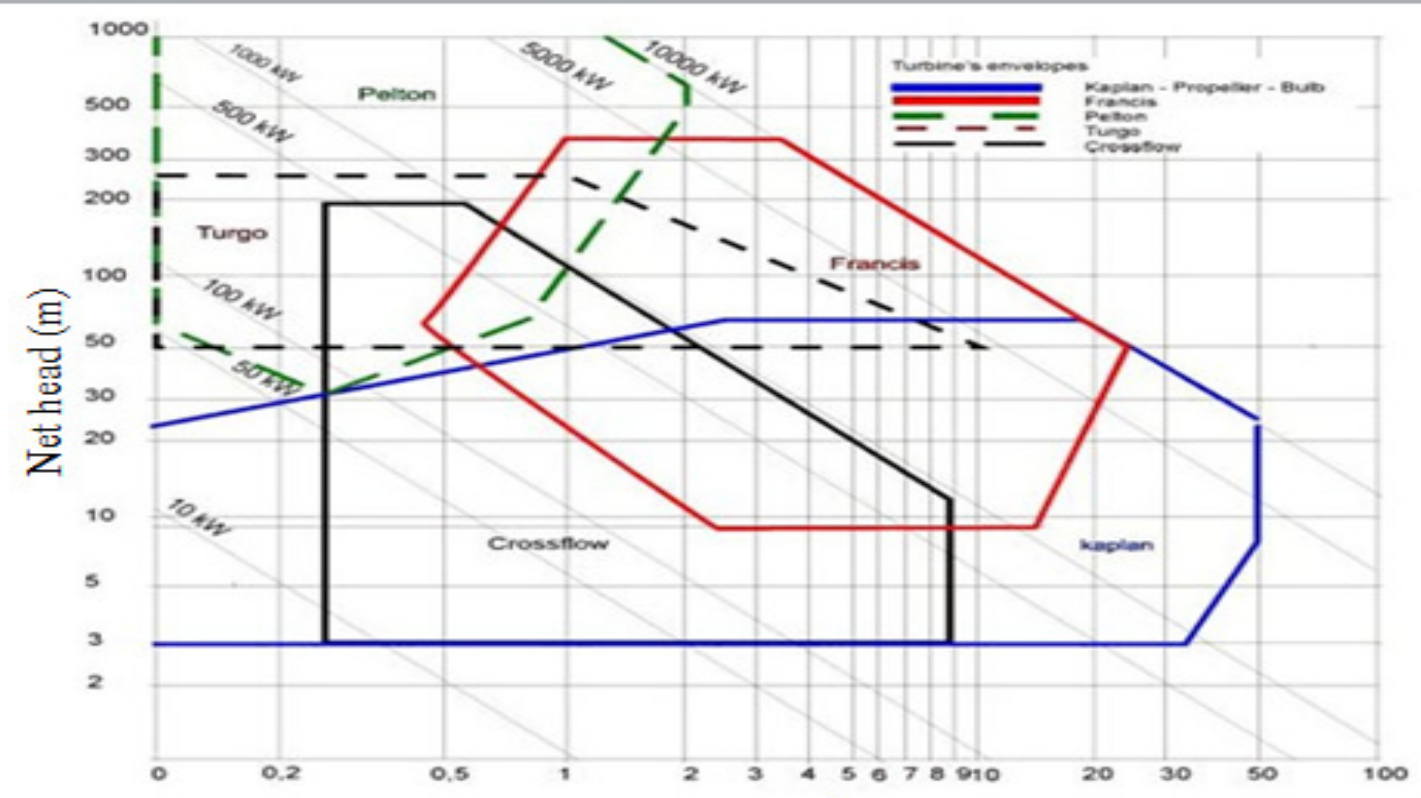

Flow $\left(\mathrm{m}^{3} / \mathrm{s}\right)$

Figure 2: Turbine application range chart [16]

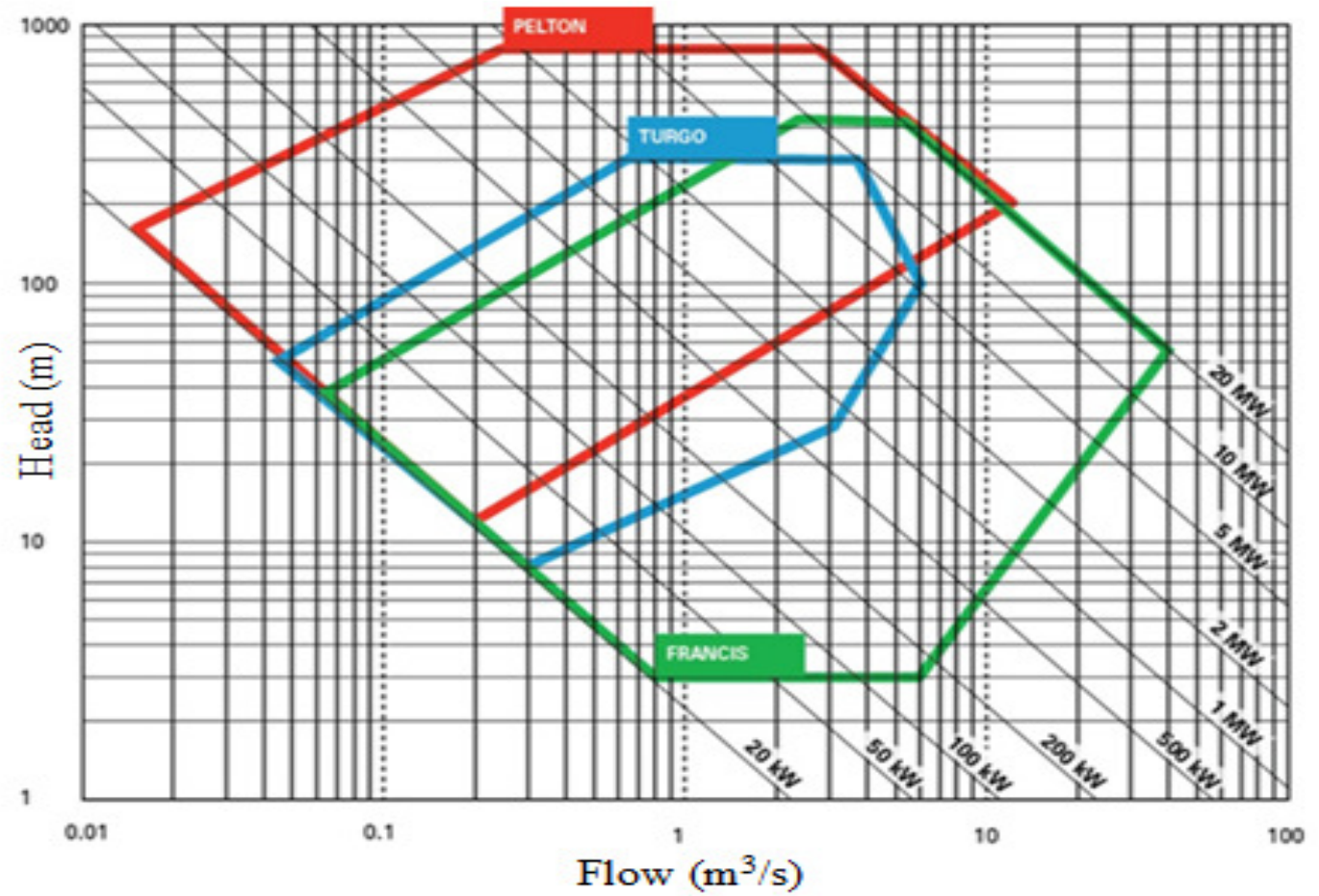

Figure 3: Turbine types and range of applications [17] 


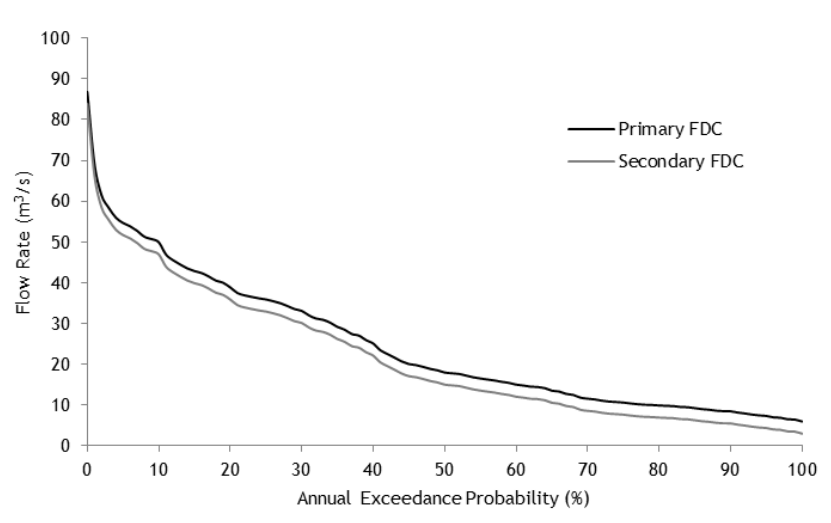

Figure 4: Primary and Secondary Flow Duration Curves for Opeki River

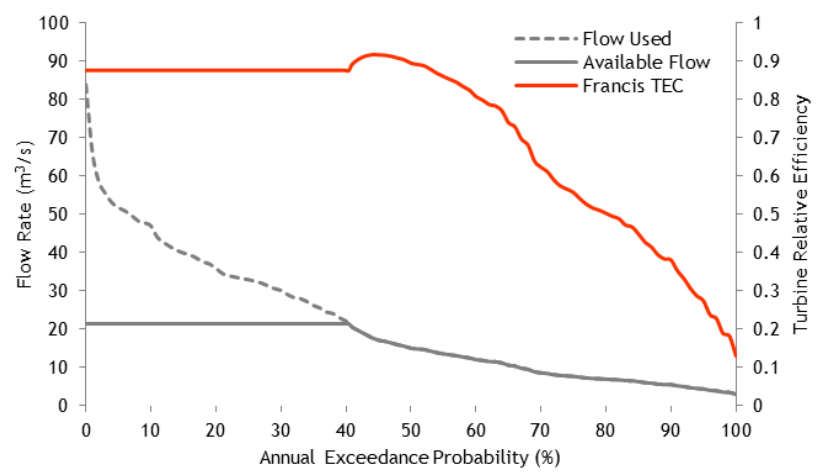

Figure 5: TEC for a single Francis turbine at $P_{\text {mean }}$

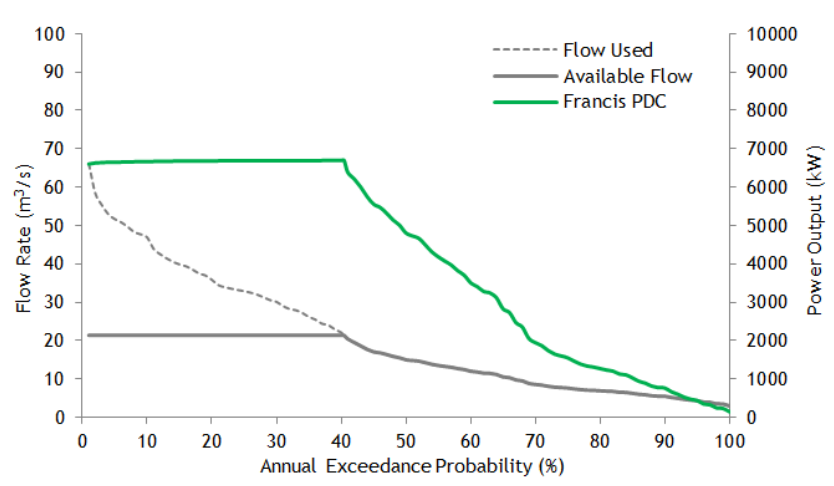

Figure 6: PDC for a single Francis turbine

The initial estimated site conditions are: gross head $\left(\mathrm{H}_{\mathrm{g}}\right)$ is $40.0 \mathrm{~m}$, maximum tailwater level $\left(\mathrm{h}_{\mathrm{w}}\right)$ is $1.0 \mathrm{~m}$ and reserved flow $\left(\mathrm{Q}_{\mathrm{r}}\right)$ is $2.97 \mathrm{~m}^{3} / \mathrm{s}$. The estimated net head from the Equation 2 is $37.0 \mathrm{~m}$. The anticipated system efficiencies and losses are: generator efficiency $\left(\eta_{\mathrm{g}}\right)$ is $98 \%$, transformer losses $\left(\zeta_{\mathrm{t}}\right)$ is $1 \%$, conduit head percentage losses $\zeta_{\mathrm{h}}$ ) is $5 \%$, parasitic electricity losses $\left(\zeta_{p}\right)$ is $1 \%$ and plant availability $(\mathrm{A})$ is $98 \%$.

A reserved flow $\left(\mathrm{Q}_{\mathrm{r}}\right)$ equal to $50 \%$ of the annual minimum flow $\left(2.97 \mathrm{~m}^{3} / \mathrm{s}\right)$ was sustained as per environmental regulations using (1). Primary and secondary flow duration curves consisting of flows available for power generation were established and presented in Figure 4.

\subsection{Power and energy assessment}

In order to estimate average power potential $\left(\mathrm{P}_{\text {mean }}\right)$, annual mean flow $\left(Q_{\text {mean }}\right)$ was taken as rated flow. An estimate of $Q_{\text {mean }}$ for the multi - year period represented by the secondary FDC was used to establish $Q_{\text {mean }}$ at $Q_{40.5}$ with its value equals $21.4 \mathrm{~m}^{3} / \mathrm{s}$. Since plant rated output was obtained from (4) when $Q_{k}=Q_{j} ;$ (4) was employed together with the appropriate turbine relative efficiencies derived from Figure 1 to compute rated output at $P_{\text {mean }}$ for Kaplan, Propeller, Francis, Crossflow, Pelton and Turgo turbines respectively.

By employing (4) along with the appropriate turbine relative efficiencies derived from Figure 1 for available flow on the secondary FDC, the variation in turbine efficiency and consequent change in plant output as annual stream flow deviates from rated flow was computed for alternative turbines. Since a turbine will only accept flows equal to or less than its rated flow when available flow exceeds the turbine's rated flow, the excess flow bypasses the turbine and the rated flow constitute the flow used for computation.

From this exercise turbine efficiency curves (TEC) and power duration curves (PDC) were plotted respectively. The turbine efficiency curve describes the variation in turbine efficiency as available flows falls below the rated flow of the turbine while the power duration curve depicts the drop in the plant rated output when available flows falls below the turbine's rated flow. Practically, the PDC defines the plant's ability to sustain output at reduced flows especially during the dry season. The exercise was repeated for the seven selected turbines, the samples of which were plotted in Figures 5 and 6. Figure 5 shows turbine efficiency curve for Francis turbine, while Figure 6 shows its PDC.

The annual energy production was projected by approximating the area of the region under the power duration curve for each turbine using Equation 8 and from the plant's annual energy production, annual capacity factor was estimated using Equation 9. The results obtained are presented in Table 1.

Though it is observed from Table 1 that Pelton and Turgo turbines are projected to give reasonably higher annual energy production in MWh. 
Table 1: Relationship between Turbines Efficiencies and $P_{\text {mean }}$

\begin{tabular}{lcccccc}
\hline $\begin{array}{c}\text { Alternative } \\
\text { Turbine } \\
\text { Types }\end{array}$ & $\begin{array}{c}\text { Efficiency } \\
\text { At Rated Flow } \\
(\%)\end{array}$ & $\begin{array}{c}\text { Peak } \\
\text { Efficiency } \\
(\%)\end{array}$ & $\begin{array}{c}\text { Lowest } \\
\text { efficiency } \\
(\%)\end{array}$ & $\begin{array}{c}\text { Plant Rated Output } \\
(\mathrm{Kw})\end{array}$ & $\begin{array}{c}\text { Annual } \\
\text { Capacity Factor } \\
(\%)\end{array}$ & $\begin{array}{c}\text { Annual Estimated } \\
\text { Energy Production } \\
\text { (Mwh) }\end{array}$ \\
\hline Kaplan & 92.0 & 92.4 & 0.0 & 7033 & 65.0 & 40000 \\
Propeller & 92.4 & 92.4 & 0.0 & 7067 & 53.1 & 32833 \\
Francis & 87.5 & 91.7 & 12.9 & 6694 & 62.1 & 36388 \\
Crossflow & 79.0 & 79.0 & 49.2 & 6042 & 64.3 & 34008 \\
1 Jet Pelton & 91.4 & 93.6 & 63.2 & 6993 & 66.9 & 40958 \\
2 Jets Pelton & 90.7 & 92.3 & 64.4 & 6940 & 66.8 & 40600 \\
1 Jet Turgo & 88.4 & 90.6 & 60.1 & 6763 & 66.9 & 39615 \\
2 Jets Turgo & 87.7 & 89.4 & 61.4 & 6711 & 66.8 & 39260 \\
\hline
\end{tabular}

Table 2: Estimation of annual energy generation from Kaplan Turbine

\begin{tabular}{ccccccc}
\hline $\begin{array}{c}\text { Suitable } \\
\text { Turbine Type }\end{array}$ & $\begin{array}{c}\text { Gross } \\
\text { Head }(\mathrm{m})\end{array}$ & $\begin{array}{c}\text { Net Head } \\
(\mathrm{m})\end{array}$ & $\begin{array}{c}\text { Efficiency at } \\
\text { Rated Flow (\%) }\end{array}$ & $\begin{array}{c}\text { Plant Rated } \\
\text { Output (kW) }\end{array}$ & $\begin{array}{c}\text { Annual Energy } \\
\text { Production (MWh) }\end{array}$ & $\begin{array}{c}\text { Capacity } \\
\text { Factor (\%) }\end{array}$ \\
\hline Kaplan & 10 & 8.5 & 90.6 & 1733 & 9507 & 62.7 \\
Kaplan & 20 & 18.0 & 92.1 & 3523 & 19797 & 64.2 \\
Kaplan & 30 & 27.5 & 92.1 & 5285 & 29934 & 64.7 \\
Kaplan & 40 & 37.0 & 92.0 & 7033 & 40000 & 65.0 \\
Kaplan & 50 & 46.5 & 91.8 & 8774 & 50012 & 65.1 \\
Kaplan & 60 & 56.0 & 91.6 & 10510 & 60000 & 65.2 \\
Kaplan & 70 & 65.5 & 91.5 & 12241 & 69966 & 65.3 \\
\hline
\end{tabular}

Table 3: Estimation of annual energy generation from Francis Turbine

\begin{tabular}{ccccccc}
\hline $\begin{array}{c}\text { Suitable } \\
\text { Turbine } \\
\text { Type }\end{array}$ & $\begin{array}{c}\text { Gross } \\
\text { Head }(\mathrm{m})\end{array}$ & Net Head $(\mathrm{m})$ & $\begin{array}{c}\text { Efficiency at } \\
\text { Rated Flow } \\
(\%)\end{array}$ & $\begin{array}{c}\text { Plant Rated } \\
\text { Output } \\
(\mathrm{kW})\end{array}$ & $\begin{array}{c}\text { Annual Energy } \\
\text { Production } \\
(\text { MWh) }\end{array}$ & $\begin{array}{c}\text { Capacity } \\
\text { Factor }(\%)\end{array}$ \\
\hline Francis & 10 & 8.5 & 65.6 & 1254 & 4585 & 41.7 \\
Francis & 20 & 18.0 & 81.3 & 3112 & 15545 & 57.1 \\
Francis & 30 & 27.5 & 85.6 & 4914 & 26072 & 60.6 \\
Francis & 40 & 37.0 & 87.5 & 6694 & 36388 & 62.1 \\
Francis & 50 & 46.5 & 88.5 & 8462 & 46607 & 62.9 \\
Francis & 60 & 56.0 & 89.1 & 10222 & 56777 & 63.4 \\
Francis & 70 & 65.5 & 89.5 & 11976 & 66902 & 63.8 \\
\hline
\end{tabular}

An examination of the turbines' application range charts in Figures 2 and 3 shows that Francis and Kaplan turbines are more practically realizable at $\mathrm{P}$ mean. $\mathrm{A}$ critical examination of Figure 5 shows that Francis turbine's efficiency is expected to decline annually from $87.5 \%$ to $12.9 \%$, at the peak of dry season. Annual energy production is estimated at $36388 \mathrm{MWh}$ as shown in Table 1. Similarly, it can be observed from Figure 5 that, Kaplan turbine's efficiency is expected to decline annually from $92.4 \%$ to $0 \%$, at the peak of dry season. Despite its total loss of efficiency at minimum flow, the Kaplan turbine exhibits better part - flow efficiency compared to the Francis turbine. Hence, annual estimated energy production with Kaplan turbine is $40000 \mathrm{MWh}$ at $65.0 \%$ capacity factor which exceeds values obtained for a single Francis turbine at $\mathrm{P}$ mean as shown in Table 1.

It was also observed from Figure 6 that the proposed plant is estimated to a have rated power output of 6.7 MW with a single Francis turbine installed. This is marginally less than the rated power output of $7.0 \mathrm{MW}$ achieved with a single Kaplan turbine. In addition, plant power output is expected to decline annually between $6.7 \mathrm{MW}$ and $142 \mathrm{~kW}$ with a single Francis turbine whereas a total loss of generation is anticipated annually with a single Kaplan turbine. The decline in power output annually is mainly due to reduction in streamflow during the dry season as observed from Figure 6.

Based on the available data considered at the study area, further analysis was carried out on Kaplan and Francis turbines to determine the effect of varying heads on turbine efficiency, plant rated power output, annual estimated energy production and capacity factor at $P$ mean for heads between $10 \mathrm{~m}$ and $70 \mathrm{~m}$, considering the aforementioned specified inputs. The results are presented in Tables 2 and 3 respectively.

From Table 2, the Kaplan turbine's efficiency at rated flow remains relatively constant at different heads. Although an increase in net head results in a significant 
increase in rated power output and estimated energy production, capacity factor at $\mathrm{P}$ mean remains relatively constant; varying marginally from $62.7 \%$ for a net head of $8.5 \mathrm{~m}$ to $65.3 \%$ for a net head of $65.5 \mathrm{~m}$. The implication of the observations in Table 2 is that a Kaplan turbine is well suited for the study area at low, medium heads and $\mathrm{P}_{\text {mean }}$. This was validated by the turbine application range chart in Figure 2.

Similarly it is observed in Table 3 that the Francis turbine's efficiency at rated flow; increases significantly from $65.6 \%$ for a net head of $8.5 \mathrm{~m}$ to $81.3 \%$ for a net head of $18 \mathrm{~m}$, with capacity factor increases significantly from $41.7 \%$ for a net head of $8.5 \mathrm{~m}$ to $57.1 \%$ for a net head of $18 \mathrm{~m}$. Although an increase in net head results in a significant increase in rated output and estimated energy production. Capacity factor remains relatively constant above a net head of $27.5 \mathrm{~m}$, varying marginally from $62.1 \%$ at a net head of $37 \mathrm{~m}$ to $63.8 \%$ at a net head of $65.5 \mathrm{~m}$. The implication of the observations in Table 3 is that Francis turbine is not well suited for the study area at low heads and $\mathrm{P}$ mean. Francis turbines, thus, perform better at $\mathrm{P}$ mean for medium heads above $30 \mathrm{~m}$ as validated by the turbine application charts presented in Figures 1 and 2.

\section{CONCLUSION}

Nigeria current electricity generation capacity is yet to meet up demand of her populace. Majority of rural and sub- urban dwellers are living far from grid system. Nigeria is blessed with a lot of streams and rivers that can be used to facilitate SHP scheme. Turbine is one of the major components of the scheme, and its function is to convert the energy in falling water to power. It is a prime mover in a hydro power station. The right choice of hydraulic turbine for any SHP site that can match up with varying seasonal water flow is a major way to optimise net power output. The energy estimates and turbine analysis made in this study indicates that optimum electrical energy from SHP can be obtained if designer follows steps described in this study. Inappropriate turbine selection often leads to significant deficit in SHP annual energy production. Results from the study shows that thorough technical knowledge on SHP turbine selection is the only way to optimize energy output from any selected SHP site.

\section{REFERENCES}

[1] United Kingdom International Hydropower Association. The Role of Hydropower in Sustainable
Development. London (Technical Communication), 2003.

[2] IEA - International Energy Agency, IHA - International Hydropower Association, ICOLD - International Commission on Large Dams, CHA - Canadian Hydropower Association, "Hydropower and the World's Energy Future: The Role of Hydropower in bringing Clean, Renewable, Energy to the World." Implementing Agreement on Hydropower Technologies and Programmes, November 2000, Paris, France, pages $1-15$.

[3] Rosnes, 0. \& Vennemo, H. Powering Up: Costing Power Infrastructure Spending Needs in Sub-Saharan Africa, African Infrastructure Country Diagnostic (AICD) Background, World Bank, Washington, DC, USA (Paper Number 5), 2008.

[4] Basnyat, D. Fundamentals of Small Hydro Power Technologies, Financing Cogeneration and Small Hydro Projects in the Sugar and Tea Industry in East and Southern Africa Training. ADB FINESSE Training Course on Renewable Energy and Energy Efficiency for Poverty Reduction, Nairobi, Kenya, 2006, 19th -

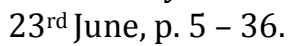

[5] Sambo, S. A. Renewable Energy for Rural Development: The Nigerian Perspective.ISESCO Science and Technology Vision, Rabat, Kingdom of Morocco, 2005, p. $12-22$.

[6] Ekpo, I. E. Hydro Potential and Development Plans in Nigeria International Journal on Hydropower and Dams, Aqua - Media International Limited, Wallington, United Kingdom. Vol 12, Number 6. 2005, p. $58-63$.

[7] Sambo, A. S. Strategic Developments in Renewable Energy in Nigeria. IAEE -International Association for Energy Economics Journal, Chicago, USA, 2009, p. 15 $-19$.

[8] United Kingdom. British Hydropower Association. $A$ Guide to United Kingdom Mini - Hydro Developments. London (Version 1.2), 2005.

[9] Belgium. European Small Hydropower Association. Guide on How to Develop a Small Hydropower Plant. Brussels, 2004.

[10] CANADA. Natural resources. Small Hydro Project Analysis Chapter, RETScreen Engineering and Cases Textbook. Ottawa (Catalogue No. M39 - 38/2003E), 2004

[11] Rajput, R. K. A Textbook of Power Plant Engineering. New Delhi: Laxmi Publications Limited, 2008.

[12] Tallaksen, L. \& Van Lanen, H. Hydrological Drought: Processes and Estimation Methods for Stream Flow and Groundwater. 1st Ed. Amsterdam: Elsevier Press, 2004.

[13] Copestake, P. \& Young, A. How Much Water Can a River Give? Uncertainty and the Flow Duration Curve. British Hydrological Society (BHS), 10 $10^{\text {th National }}$ 
Hydrology Symposium, Exeter, United Kingdom, 2002.

[14] Kaunda, C., Kimambo, C. \& Nielsen, T. Potential of Small - Scale Hydropower for Electricity Generation in Sub - Saharan Africa ISRN Renewable Energy Journal, Hindawi, New York, USA, 2012, pp. 1 - 15.

[15] Shobayo, D., Adejumobi, I., Awokola, O. and Akinwale, A., "An Assessment of the Small Hydro Potential of Opeki River, Southwestern Nigeria", Science Journal of Energy Engineering. Vol. 2, Number 3, 2014, pp. 25 $-31$
[16] Penche, C., "Layman's Guide on How to Develop a Small Hydro Site" $2^{\text {nd }}$ Edition, Directorate - General for Energy, Commission of European Communities, Brussels, Belgium, 1998.

[17]Gilbert Gilkes and Gordon Ltd., "Hydropower: Turbine Selection," Cumbria, United Kingdom, 2014. http://www.gikes.com/ Turbine-Selection 